\title{
A multiple gestation in a Delphinus delphis stranded on the north-western Spanish coast
}

\author{
Angel F. González, Alfredo López and Pedro Benavente* \\ Instituto de Investigaciones Marinas, Eduardo Cabello 6, E-36208 Vigo, Spain \\ *CEMMA-CES, Apartado 100, E-36980 O Grove, Spain
}

\begin{abstract}
The present study is the first record of twinning in Delphinus delphis. The first foetus was a female of $72 \mathrm{~cm}$ total length which had a curved caudal area. This animal was located in the left uterine horn, very close to the genital aperture. The second foetus was a male of $46 \mathrm{~cm}$ total length and its external morphology was deformed. It was located in the uterus and the nose was shorter than the female foetus. Documented incidences of twinning in cetaceans are rare.
\end{abstract}

The incidence of twinning in delphinids is rare and has not been previously observed for common dolphins (Delphinus delphis Linnaeus, 1758). This species is perhaps one of the most widely distributed species of cetacean, as it is found world-wide in temperate, tropical and subtropical seas (Evans, 1994). This small cetacean rarely reaches a total length longer than $2.5 \mathrm{~m}$. In the north-eastern Atlantic, common dolphins appear to be present over the continental shelf near the $200 \mathrm{~m}$ isobath or over prominent underwater topography. The behaviour of these animals is gregarious. Status of the population in the northwestern Spanish waters is unknown but $D$. delphis is not listed as a threatened or endangered species in this area. However, 81 strandings of this species were recorded during 1998 along the Galician coast which is almost $50 \%$ of all strandings observed in this region during 1998. Therefore, this species appears to be the most frequently occurring coastal species of cetacean in Galician waters.

A female D. delphis, was found floating in a medium stage of decomposition (stage 3; Kuiken \& García-Hartmann, 1991) and was taken ashore to the village of $\mathrm{O}$ Grove $\left(42^{\circ} 30^{\prime} \mathrm{N} 8^{\circ} 53^{\prime} \mathrm{W}\right)$ on 7 June 1998. Total length of the specimen was $203 \mathrm{~cm}$, and there was no external damage or wounds except some small superficial cuts, apparently made by a knife in the border of the caudal peduncle. Additional measurements of the specimen are summarized in Figure 1. Dentition was complete. Externally, there was no evidence of any abnormal feature. Left ovary was large $(13.8 \mathrm{~g})$, bilobulated and it had two corpus luteum as well as three surface scars. Right ovary was small $(1.3 \mathrm{~g})$, without scars or corpus luteum. External walls of the uterus had slender protuberances of sandy consistency. These protuberances were also observed in the intestinal walls and the intestine was dilated. Liver and lungs were normal, lacking parasites. No mesenteric or subcutaneous parasites were found. The stomach contained no food remains (except one fish otolith), but it was full of the nematode Anisakis sp. which probably caused a large ulcer $(2 \times 1.5 \mathrm{~cm})$ that was healing. There were also scars from two completely healed ulcers.

After dissection, the first foetus was removed. It was a female of $72 \mathrm{~cm}$ total length which had a curved caudal area (Figure 2). This foetus had four teeth erupted but the remaining ones appeared only as slight protuberances. This animal was located in the left uterine horn, very close to the genital aperture. The second foetus was a male of $46 \mathrm{~cm}$ total length, and its external

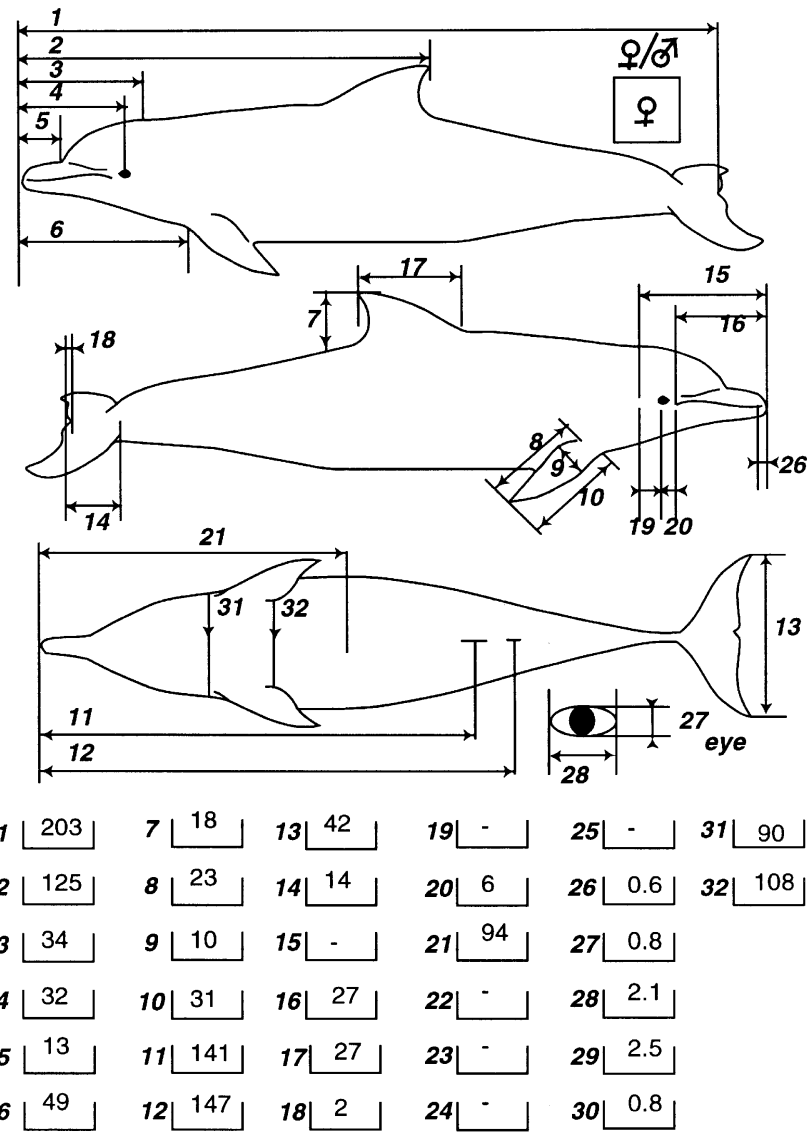

Figure 1. Schematic drawing of the pregnant female and measurements taken.

morphology was deformed with a shorter nose than the female foetus (Figure 2). The male was located in the uterus.

Multiple foetuses are less frequent in Odontoceti than in Mysticeti (Lockyer, 1984). Like all animals, aberrations occur during the development of the foetus in Cetacea. Nearly all this information has come from whaling data (Lockyer, 1984). Information about multiple gestation in whales has occasionally been reported for Mysticeti (Kawamura, 1969; Zemsky \& Budylenko, 1970; Ivashin \& Zinchenko, 1982). However, after a detailed review of the literature about Odontoceti, only a few records of multiple gestation were found. Twin embryos were found only 


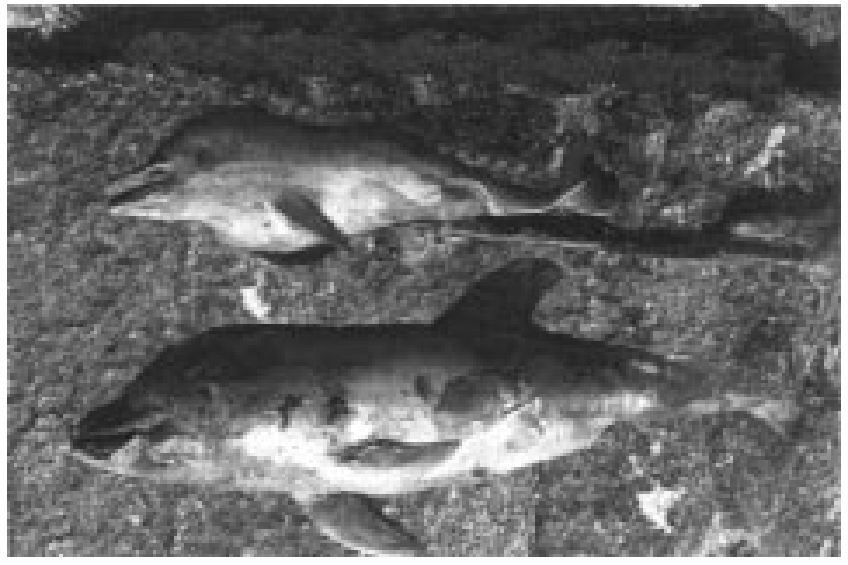

Figure 2. Male $(46 \mathrm{~cm}$ total length, above) and female $(72 \mathrm{~cm}$ total length, below) calves found dead in the uterus of the pregnant female.

once after the examination of 49 pregnant female beluga at the Churchill region of Hudson Bay (Doan \& Douglas, 1953). Furthermore, an abortion of two calves from an approximately 10 -y old beluga was reported by Dalton \& Robeck (1996). On the other hand, analysis of 529 mature females of Globicephala melas revealed no incidence of multiple gestation, although abnormalities in the reproductive tract were sometimes observed (Sergeant, 1962). There was only one observation of twins in the tropical pilot whale Globicephala macrorhynchus (Escorza et al., 1994) and one in the sperm whale Physeter macrocephalus (Gambell, 1972). Concerning small Odontoceti, there are only three observations of twins of the bottlenose dolphin, Tursiops truncatus (Gray \& Conklin, 1974; Ridgway \& Benirschke, 1974; Amundin et al., 1989). This observation of multiple gestation in D. delphis is the first one reported to date after the dissection of more than 800 specimens of small cetaceans carried out in Galicia during the period 1990-1998. However, V. Cockroft (personal communication) has seen only one set of twin foetuses after dissecting more than 1500 specimens of different species of delphinids.

The few observations in small cetaceans of twins to births of multiple gestations indicate that the event is extremely rare and occurs in less than $0.5 \%$ of all observed pregnant females. Furthermore, most of these observations were made on animals in captivity. Why captive females show a higher incidence of twins remains a mystery and therefore, more studies are needed to gain more information about this rare event.

We are grateful to Dr Vic Cockroft (Centre for Dolphin Studies, South Africa) for his valuable information about twin foetuses in delphinids, Dr Angel Guerra for his valuable suggestions on the manuscript and Mr Joaquín Gracia for the photographs. We also thank the anonymous referees for their valuable comments. This research forms part of the Project
'Impacts of fisheries on small cetaceans in coastal waters of north-west Spain and Scotland' (reference no. PC97/0089).

\section{REFERENCES}

Amundin, M., Hultman, S. \& Roken, B., 1989. Bottle-nosed dolphins twin birth in Kolmarden Dolphinarium. In Proceedings of the Seventeenth Conference of the International Marine Mammal Trainers Association, The Netherlands, October-November 1989.

Dalton, L.M. \& Robeck, D.V.M., 1996. Twin foetuses from a beluga whale (Delphinapterus leucas). Proceedings of the 1996 IAAAM, pp. 65.

Doan, K.H. \& Douglas, C.W., 1953. Beluga of the Churchill region of Hudson Bay. Bulletin of the Fisheries Research Board of Canada, 98, 27 pp.

Escorza, S., Nakayama, I. \& Kawamura, A., 1994. Cetacean DNA fingerprinting using the oligonucleotide (GGAT) 4 as a probe. Marine Biology, 120, 339-342.

Evans, W.E., 1994. Common dolphin, white-bellied porpoise Delphinus delphis Linnaeus, 1758. In Handbook of marine mammals (ed. S.H. Ridgway and R. Harrison), pp.191-224. Cambridge: Academic Press.

Gambell, R., 1972. Sperm whales off Durban. In Oceanography, N.I.O.: Discovery Reports, vol.35, pp. 199-358. Cambridge: Whale Research Unit, National Institute of Oceanography, Cambridge.

Gray, K.N. \& Conklin, R.H., 1974. Multiple births and cardiac anomalies in the bottle-nosed dolphin. Fournal of Wildlife Diseases, 10, 155-157.

Ivashin, M.V. \& Zinchenko, V.L., 1982. Occurrences of pathological development of minke whale embryos (Balaenoptera acutorostrata) of the Southern Hemisphere. Paper SC/34/Mi29 presented to the IWC Scientific Committee, Cambridge, Fune 1982, $25 \mathrm{pp}$.

Kawamura, A., 1969. Siamese twins in the sei whale, Balaenoptera borealis (Lesson). Nature, London, 221, 490-491.

Kuiken, T. \& García-Hartmann, M., 1991. Dissection techniques and tissue sampling. Proceedings of the First ECS Workshop on Cetacean Pathology, Leiden, The Netherlands, 13-14 September 1991, $39 \mathrm{pp}$.

Lockyer, C., 1984. Review of Baleen whale (Mysticeti) reproduction and implications for management. In Reproduction on whales, dolphins and porpoises (ed. W.F. Perrin et al.), pp. 27-50. Cambridge: Reports of the International Whaling Commission.

Ridgway, S.H. \& Benirschke, K., ed., 1974. Breeding dolphins, present status, suggestions for the future. In National Technical Information Service, United States Department of Commerce, pp. 308.

Sergeant, D.E., 1962. The biology of the pilot or pothead whale Globicephala melaena in Newfoundland waters. Bulletin of the Fisheries Research Board of Canada, 132, 1-84.

Zemsky, V.A. \& Budylenko, G.A., 1970. Siamese twins of humpback whale. Whales of the Southern Hemisphere. Trudy Atlant NIRO, 29, 225-230.

Submitted 4 January 1999. Accepted 27 April 1999. 